\title{
The in vitro protein degradability of legume and sudan grass forage types and ensiled mixtures
}

\author{
Bojan STOJANOVIĆ1,a, ${ }^{,}$, Nenad ĐORĐEVIĆ ${ }^{1, b}$, Aleksandar SIMIĆc,c, Aleksa BOŽIČKOVIĆ',d, \\ Vesna DAVIDOVIĆ ${ }^{1, \mathrm{e}}$, Aleksandra IVETIĆ ${ }^{1, \mathrm{f}}$ \\ ${ }^{1}$ University of Belgrade, Faculty of Agriculture, Department of Animal Science, Belgrade; ${ }^{2}$ University of Belgrade, Faculty of \\ Agriculture, Department of Crop Science, Belgrade, Serbia. \\ aORCID: 0000-0001-5057-1790; ' $\mathrm{ORCID:} \mathrm{0000-0003-4196-4773;} \mathrm{'}{ }^{\mathrm{O} C R C I D:}$ 0000-0002-7605-3796; \\ ${ }^{\mathrm{d}}$ ORCID: 0000-0002-8671-4906; ' $\mathrm{ORCID:} \mathrm{0000-0003-0764-3183;} \mathrm{f} \mathrm{ORCID:} \mathrm{0000-0003-2762-1870}$
}

Corresponding author: arcturas@agrif.bg.ac.rs Received date: 11.03.2020 - Accepted date: 09.06.2020

\begin{abstract}
This study examined the in vitro crude protein (CP) degradability of wilted, dried for hay and ensiled Medicago sativa, Trifolium pratense and Sorghum sudanense, as well as of ensiled legume-sudan grass mixtures. The rumen degradable protein (RDP) was estimated using the latest Cornell net carbohydrate and protein system (CNCPS v6.5) and with the Streptomyces griseus protease assay (48 h of incubation). Sudan grass forages were the lowest in moderately degradable CP and the highest in CP fraction C, while red clover showed the least values for the soluble true protein like alfalfa forages for slowly degradable protein bound in neutral detergent fibre (NDF). Ensiling of legume-sudan grass mixtures decreases $\mathrm{N}^{-\mathrm{NH}_{3}}$ content by 12.2 and $5.1 \%$ in comparison with alfalfa and red clover silages, respectively. The RDP values for sudan grass (fresh, wilted, hay) were lower by 7.2 to $7.9 \%$ or 10.4 to $15.7 \%$ (CNCPS or S. griseus procedure) and up to 0.8 or 5.3 to $9.7 \%$ in comparison with alfalfa and red clover, respectively. The reduction of protein degradability in ensiled legume-sudan grass mixtures was 5.5 or $6.1 \%$ and 1.5 or $3 \%$ compared to alfalfa and red clover silages, respectively. Due to higher rumen undegradable protein content, the sudan grass and legume-sudan grass mixtures may be efficiently used to improve the protein utilization in ruminant nutrition.
\end{abstract}

Key words: Alfalfa, protein fractions, red clover, ruminants, sudan grass.

\section{Introduction}

The accuracy of diet formulation for ruminants demands true rumen degradability parameters for crude protein $(\mathrm{CP})$ in the ration. The efficiency of nitrogen conversion in milk production is 18 to $30 \%$, and in meat production 10 to $20 \%$, which is far below the potential of cattle, which exceeds $40 \%$ (9). Overfeeding of dietary nitrogen due to the inaccurate prediction of the animal requirements and dietary content of degradable and undegradable protein leads to inefficient ruminal utilization of feed $\mathrm{N}$, which is related directly to $\mathrm{NH}_{3}$ emission from cattle manure (15). These losses are caused on the one hand by rapid and excessive degradation of plant protein, and improving the efficiency of nitrogen utilization can be achieved by reducing the degree of protein degradation in the rumen (8). For these reasons, many studies have focused on strategies to improve nitrogen balance in milk and meat production based on the legume and grass forages $(5,24,9)$. Solubility and degradability of forage protein change during wilting and preservation (6). The changes in protein quality during hay-making, wilting and ensiling of legume and grass forages can affect intake, protein utilization and productivity of dairy and beef cattle (13).

Legume forages are an important source of protein for ruminants, but its protein is often poorly used because it is extensively degraded during ruminal fermentation, and this may be the most limiting factor of high-quality forage legumes (26). Considering the higher content of NDF and higher values for slowly degradable protein bound in NDF which are usually greater in grasses than in legumes (7), grass and legume-grass forages may have positive effect and reduce the degradability of dietary CP. For that reason, the sudan grass forages could be important for improving the profile of $\mathrm{CP}$ in ruminant diets where the ensiling of legume-sudan grass mixtures may be of particular interest. Sudan grass has become an important crop for the production of forage mass for grazing, silage and hay, for dairy and beef producers in areas with lack or not well distributed rainfall throughout a year (23). Sudan grass is currently the only warm-season grass occasionally overseeded into alfalfa in late spring or summer, when 
alfalfa has been severely damaged from winter flooding and it is too late to plant other (cool season) species (3).

The objective of this study was to quantify the crude protein fractions and degradability of different types of alfalfa, red clover and sudan grass forages as well as the effects of ensiling legume-sudan grass mixtures on reduction of forage protein degradability. To analyze and compare the composition and degradability of $\mathrm{CP}$, new fractionation scheme CNCPS v6.5 (Cornell Net Carbohydrate and Protein System) as well as the Streptomyces griseus protease assay were used.

\section{Material and Methods}

Forage material and sample preparation: The trial included wilted, dried for hay and ensiled alfalfa, red clover and sudan grass, as well as ensiled alfalfa-sudan grass and red clover-sudan grass mixtures. Forage material used in this study included: the first cut sudan grass (Sorghum sudanense (Piper) Stapf., cultivar Srem, Institute of Field and Vegetable Crops, Novi Sad) harvested at the early-heading stage; the third cut alfalfa (Medicago sativa L., cultivar NS Mediana ZMS V, Institute of Field and Vegetable Crops, Novi Sad) at late bud stage; the third cut red clover (Trifolium pratense L., cultivar K-17 Institute for Forage Crops Kruševac) at 10\% bloom stage. The experiment was carried out during the 2016, plants were harvested from fields with pure stands located in the central region of Serbia, near Velika Plana $\left(44^{\circ} 17^{\prime} \mathrm{N}, 21^{\circ} 05^{\prime} \mathrm{E}\right)$. Sudan grass was cut at a height of 100 $\mathrm{mm}$ while alfalfa and red clover at $50 \mathrm{~mm}$ by a sickle bar mower. For the wilting treatment, the fresh herbage samples were allowed to wilt for $8 \mathrm{~h}$ during a sunny day at 24 to $37^{\circ} \mathrm{C}$. The herbage material was placed in a thin layer on a clean plastic sheet, and a twice for a wilting time the herbage was manually tedded. Herbage was dried for hay in conditions described for wilting treatment, whereby the plant material stayed outdoor and overnight, with manual turning twice a daily to promote drying, until a dry matter (DM) content of $\geq 850 \mathrm{~g} / \mathrm{kg}$ was reached. For ensiling treatment, after wilting time of $8 \mathrm{~h}$ the plant material was chopped to approximately $1.2 \mathrm{~cm}$ particle length with a simple straw chopper. A required part of crop material was used for the preparation of alfalfa-sudangrass and red clover-sudangrass mixture (1:1 ratio, as fed basis). All herbage was ensiled without the use of inoculants in anaerobic glass jars of 1.51 capacity, each jar contained 600 to $700 \mathrm{~g}$ of herbage mass. Silages were stored at room temperature for 4 months. For each forage species and mixture, five laboratory silos with ensiled plant material were prepared.

Analytical procedures: All samples were analyzed in the Laboratory of the Animal Nutrition at the Faculty of Agriculture, University of Belgrade. The samples of the fresh and wilted plant material and silages were dried at $50^{\circ} \mathrm{C}$ in a forced-air oven for $48 \mathrm{~h}$, for the analysis of chemical composition. All samples were ground through a $1 \mathrm{~mm}$ diameter screen on a small-sample cutting mill (Kinematica PX-MFC 90D). Ground samples were analyzed according to the Official Methods (2). DM levels of samples were determined by drying at $105^{\circ} \mathrm{C}$ for $16 \mathrm{~h}$ (method 967.03). Ash was determined by combustion at $600^{\circ} \mathrm{C}$ for $2 \mathrm{~h}$ (method 942.05). The $\mathrm{CP}$ content was determined by Kjeldahl method (method 2001.11) using $\mathrm{K}_{2} \mathrm{SO}_{4} / \mathrm{Cu}$ catalyst-Kjeltabs S 3.5, on the Kjeltec Auto 1030 Analyzer-Tecator System. Ether extract content was determined by extraction using diethyl-ether in the Soxhlet apparatus (method 920.39). NDF content was determined using heat-stable $\alpha$-amylase (A3306 Sigma Chemical Co., St Louis, MO, USA) according to the Official Method 2002.04, without use of sodium sulphite, and without correction for ash content. The ADF was determined according to the Official Method 973.18 without correction for ash content. Water extracts of ensiled forage (22) were analyzed for $\mathrm{pH}$ using an HI 9017 Microprocessor $\mathrm{pH}$ Meter Hanna Instruments.

Separating of CP into five fractions (A1, A2, B1, B2 and $\mathrm{C}$ ) based on characteristics of degradability was done according to the CNCPS v6.5 (14). Within determined fractions, A1 represents $\mathrm{NH}_{3}$ (as CP equivalents), A2 soluble true protein (soluble protein minus A1), B1 buffer insoluble protein minus neutral detergent insoluble protein (NDIP), B2 NDIP minus acid detergent insoluble protein (ADIP), and ADIP the $\mathrm{C}$ fraction. The $\mathrm{NH}_{3}-\mathrm{N}$ analysis was performed following the procedure of AOAC 941.04 with $\mathrm{N}$ determination by Kjeldahl method. The other fractions of $\mathrm{CP}$ were determined according to the standardizations of Licitra et al. (19). For soluble true protein determination, the borate-phosphate buffer having pH 6.7 and sodium azide was used. The content of all proteins in the CNCPS are calculated as $\mathrm{N} \times 6.25$. Rumen degradable protein was estimated from fractions A1, A2, B1 and B2, using digestion rate constants of 200\%/h, 10 to $40 \% / \mathrm{h}, 3$ to $20 \% / \mathrm{h}$ and 1 to $18 \% / \mathrm{h}(27)$, with assumed passage rate $(\mathrm{Kp})$ of $5 \% / \mathrm{h}(24)$.

Enzymatic in vitro procedure for simulated rumen protein degradation was conducted using Streptomyces griseus protease (type XIV, Sigma Chemical Co., Catalog No. P5147) contained $4.0 \mathrm{U} / \mathrm{mg}$, according to the protocol described by Coblentz et al. (4). Triplicate forage samples containing $15 \mathrm{mg}$ of $\mathrm{N}$ were incubated in $40 \mathrm{ml}$ of a boratephosphate buffer solution ( $\mathrm{pH} 7.8$ to 8.0 ) for $1 \mathrm{~h}$ at $39^{\circ} \mathrm{C}$. Subsequently, $10 \mathrm{ml}$ of separate protease solution with an enzyme activity of $0.33 \mathrm{U} / \mathrm{ml}$ was added to the boratephosphate buffer plus forage (resulted in final enzyme concentration of $0.066 \mathrm{U}$ of activity/ml and a ratio of 0.22 $\mathrm{U} / \mathrm{mg} \mathrm{N}$ ) and incubated for $48 \mathrm{~h}$. The fixed ratio of units of enzyme/ $\mathrm{N}$ was reached by considering the content of $\mathrm{CP}$ in analyzed forages. Following incubation, the samples 
were vacuum filtered through Whatman \#541 filter paper. To calculate enzyme protein degradability (EPD) the following equation was used:

EPD $(\%)=(1.0-(\mathrm{N}$ in residue $(\mathrm{mg}) / \mathrm{N}$ in sample $(\mathrm{mg}))) \times 100$.

Statistical analysis: A factorial ANOVA procedure (The General Linear Model Analysis) using the STATISTICA v.6 (25) was conducted to assess the effects of crop (alfalfa, red clover and sudan grass) and type of forage (fresh, wilted or hay), as well as one-way ANOVA for evaluating the effect of ensiled forage crop or binary mixtures, on $\mathrm{N}$ fractions contents and in vitro crude protein degradability. Differences among treatment means were tested for significance using TUKEY multiple comparison test. Linear regression using the CURVEEXPERT PROFESSIONAL v.2.6.3. (16) was applied to compare RDP estimates for analyzed forages, with the values obtained from the enzymatic procedure as the independent variable and the values based on CP fractionation as the dependent variable, and with relationships described using the coefficient of determination $\left(\mathrm{R}^{2}\right)$. Overall differences between treatment means were considered to be significant when $\mathrm{P}<0.05$. Confidence level for regression models was $\mathrm{P}<0.01$.

\section{Results}

Different forage treatments had a negligible effect on the levels of DM components. The CP was substantially lower in sudan grass than in red clover and particular alfalfa forage (Table 1). However, sudan grass forage had the highest fiber levels (NDF and ADF). The DM content of silages was similar to the wilted material. Sudan grass silage was significantly lower $(\mathrm{P}<0.001)$ in $\mathrm{CP}$ and higher in $\mathrm{NDF} \quad(\mathrm{P}<0.05)$ and $\mathrm{ADF} \quad(\mathrm{P}<0.05)$ content in comparison to ensiled legumes, while ensiled legumesudan grass mixtures were intermediate according to chemical composition.

The $\mathrm{pH}$ values of silages were determined as 4.61 , 4.87, 4.73, 4.80 and 4.69 for sudan grass, alfalfa, red clover, alfalfa-sudan grass and red clover-sudan grass mixture, respectively.

Table 1. Dry matter (DM) and chemical composition of forages (g/kg DM).

\begin{tabular}{|c|c|c|c|c|c|c|c|c|c|c|}
\hline \multirow{2}{*}{ Forage } & \multicolumn{2}{|c|}{ DM } & \multicolumn{2}{|c|}{$\mathrm{CP}$} & \multicolumn{2}{|c|}{ NDF } & \multicolumn{2}{|c|}{ ADF } & \multicolumn{2}{|c|}{$\mathbf{E E}$} \\
\hline & Mean & SEM & Mean & SEM & Mean & SEM & Mean & SEM & Mean & SEM \\
\hline \multicolumn{11}{|l|}{ Sudan grass } \\
\hline Fresh & 209.8 & 5.5 & 98.4 & 4.5 & 599.2 & 7.1 & $383.1^{\mathrm{a}}$ & 2.2 & 30.7 & 1.4 \\
\hline Wilted & 301.8 & 5.1 & 96.1 & 3.2 & 623.7 & 9.9 & 397.7 & 5.2 & 32.9 & 1.2 \\
\hline Hay & 851.6 & 0.1 & 100.4 & 0.7 & 625.8 & 2.8 & $420.2^{\mathrm{b}}$ & 6.1 & 29.1 & 1.1 \\
\hline$P$ & - & & 0.995 & & 0.481 & & 0.003 & & 0.840 & \\
\hline \multicolumn{11}{|l|}{ Alfalfa } \\
\hline Fresh & 239.2 & 6.8 & 226.6 & 1.6 & 443.0 & 1.8 & $315.2^{\mathrm{a}}$ & 4.7 & 29.0 & 1.4 \\
\hline Wilted & 389.5 & 4.4 & 229.3 & 4.6 & 438.7 & 5.1 & 335.5 & 9.7 & 33.2 & 1.2 \\
\hline Hay & 875.0 & 2.4 & 224.3 & 0.3 & 458.8 & 1.4 & $349.4^{\mathrm{b}}$ & 7.7 & 31.6 & 0.7 \\
\hline $\mathrm{P}$ & - & & 0.980 & & 0.849 & & 0.008 & & 0.731 & \\
\hline \multicolumn{11}{|l|}{ Red clover } \\
\hline Fresh & 248.4 & 6.1 & 174.9 & 2.3 & 477.1 & 4.5 & 357.2 & 5.4 & 33.8 & 3.2 \\
\hline Wilted & 369.8 & 4.9 & 175.2 & 3.1 & 487.3 & 5.6 & 359.3 & 9.4 & 31.1 & 1.5 \\
\hline Hay & 867.8 & 1.9 & 176.5 & 1.4 & 488.0 & 1.5 & 353.5 & 3.8 & 32.1 & 0.4 \\
\hline $\mathrm{P}$ & - & & 1.00 & & 0.831 & & 0.952 & & 0.986 & \\
\hline \multicolumn{11}{|l|}{ Silage } \\
\hline Sudan grass & $313.9^{\mathrm{a}}$ & 7.0 & $108.4^{\mathrm{a}}$ & 0.3 & $616.9^{a}$ & 10.1 & $412.8^{\mathrm{a}}$ & 4.8 & 33.5 & 1.1 \\
\hline Alfalfa & $396.9^{\mathrm{b}}$ & 6.1 & $234.7^{\mathrm{b}}$ & 2.1 & $451.5^{\mathrm{b}}$ & 9.8 & $349.2^{\mathrm{b}}$ & 3.3 & 36.5 & 1.4 \\
\hline Red clover & $378.6^{\mathrm{b}, \mathrm{d}}$ & 7.1 & $178.9^{c}$ & 1.5 & $504.7^{\mathrm{c}}$ & 11.7 & $362.9^{\mathrm{b}, \mathrm{c}}$ & 2.2 & 36.6 & 1.4 \\
\hline $\mathrm{AF} \times \mathrm{SG}$ & $347.2^{\mathrm{c}}$ & 7.1 & $150.2^{\mathrm{d}}$ & 2.3 & $547.5^{\mathrm{d}}$ & 13.0 & $378.5^{c}$ & 3.9 & 32.9 & 1.5 \\
\hline $\mathrm{RC} \times \mathrm{SG}$ & $354.0^{\mathrm{c}, \mathrm{d}}$ & 6.9 & $119.1^{\mathrm{a}}$ & 3.0 & $563.3^{\mathrm{d}}$ & 9.8 & $383.7^{c}$ & 5.5 & 34.0 & 1.1 \\
\hline$P$ & 0.037 & & $<0.001$ & & 0.020 & & 0.046 & & 0.883 & \\
\hline
\end{tabular}

$\mathrm{AF} \times \mathrm{SG}$ : Alfalfa-sudan grass mixture; $\mathrm{RC} \times \mathrm{SG}$ : Red clover-sudan grass mixture; $\mathrm{CP}$ : Crude protein; NDF: Neutral detergent fibre;

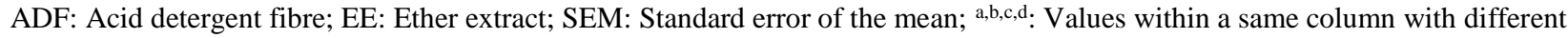
numerical superscripts differ significantly $(\mathrm{P}<0.05)$. 
Table 2. The CNCPS crude protein fractions of fresh and wilted herbage and hay (g/kg CP).

\begin{tabular}{|c|c|c|c|c|c|c|c|}
\hline \multirow{2}{*}{$\begin{array}{l}\text { CP fraction/ } \\
\text { Forage }\end{array}$} & \multicolumn{2}{|c|}{ Sudan grass } & \multicolumn{2}{|c|}{ Alfalfa } & \multicolumn{2}{|c|}{ Red clover } & \multirow{2}{*}{$\mathbf{P}$} \\
\hline & Mean & SEM & Mean & SEM & Mean & SEM & \\
\hline \multicolumn{8}{|l|}{ Fraction A1 } \\
\hline Fresh & 2.5 & 0.4 & 4.3 & 0.3 & 4.1 & 1.3 & 1.00 \\
\hline Wilted & 3.7 & 0.5 & 7.2 & 0.3 & 5.1 & 0.8 & 0.999 \\
\hline Hay & 5.9 & 0.7 & 9.2 & 0.6 & 5.2 & 1.0 & 0.979 \\
\hline $\mathrm{P}$ & 0.998 & & 0.997 & & 1.00 & & \\
\hline \multicolumn{8}{|l|}{ Fraction A2 } \\
\hline Fresh & $357.1^{\mathrm{x}}$ & 7.2 & $322.0^{x}$ & 1.1 & $262.5^{y}$ & 4.8 & $<0.001$ \\
\hline Wilted & $385.0^{x}$ & 17.9 & $356.6^{x}$ & 6.2 & $277.9^{y}$ & 2.8 & $<0.001$ \\
\hline Hay & $385.6^{x}$ & 10.7 & $343.4^{x}$ & 8.6 & $296.4^{y}$ & 5.2 & 0.031 \\
\hline$\underline{P}$ & 0.585 & & 0.286 & & 0.313 & & \\
\hline \multicolumn{8}{|l|}{ Fraction B1 } \\
\hline Fresh & $337.4^{x}$ & $8 . .3$ & $491.4^{y}$ & 2.6 & $502.7^{y}$ & 4.5 & $<0.001$ \\
\hline Wilted & $333.9^{x}$ & 15.5 & $476.7^{y}$ & 9.9 & $497.5^{y}$ & 4.3 & $<0.001$ \\
\hline Hay & $309.2^{\mathrm{x}}$ & 12.2 & $474.8^{y}$ & 17.2 & $459.0^{y}$ & 9.1 & $<0.001$ \\
\hline $\mathrm{P}$ & 0.890 & & 0.999 & & 0.318 & & \\
\hline \multicolumn{8}{|l|}{ Fraction B2 } \\
\hline Fresh & $189.3^{\mathrm{x}}$ & 7.4 & $127.5^{y}$ & 4.5 & $169.2^{\mathrm{x}}$ & 1.3 & $<0.001$ \\
\hline Wilted & $168.3^{x}$ & 2.3 & $117.7^{y}$ & 5.4 & $162.6^{x}$ & 1.8 & $<0.001$ \\
\hline Hay & $175.7^{x}$ & 1.0 & $122.1^{y}$ & 9.0 & $170.1^{x}$ & 9.5 & $<0.001$ \\
\hline $\mathrm{P}$ & 0.235 & & 0.984 & & 0.998 & & \\
\hline \multicolumn{8}{|l|}{ Fraction $\mathrm{C}$} \\
\hline Fresh & $113.7^{\mathrm{a}, \mathrm{bx}}$ & 3.0 & $54.8^{\text {a y }}$ & 2.8 & $61.6^{\mathrm{a}, \mathrm{b} y}$ & 4.3 & $<0.001$ \\
\hline Wilted & $109.1^{\mathrm{ax}}$ & 2.3 & $41.8^{\text {by }}$ & 2.7 & $56.9^{a z}$ & 3.7 & $<0.001$ \\
\hline Hay & $123.6^{\mathrm{bx}}$ & 1.8 & $50.5^{\mathrm{a}, \mathrm{b} y}$ & 2.1 & $69.3^{\mathrm{bz}}$ & 2.0 & $<0.001$ \\
\hline $\mathrm{P}$ & 0.002 & & 0.009 & & 0.016 & & \\
\hline
\end{tabular}

SEM: Standard error of the mean; ${ }^{\text {a,b }}$ : Values within a same column with different numerical superscripts differ significantly $(\mathrm{P}<0.05) ;{ }^{x, y, z}$ : Values within a same row with different letter superscripts differ significantly $(\mathrm{P}<0.05)$.

Table 3. The CNCPS crude protein fractions of silages $(\mathrm{g} / \mathrm{kg} \mathrm{CP})$.

\begin{tabular}{|c|c|c|c|c|c|c|c|c|c|c|}
\hline \multirow{3}{*}{ Ensiled herbage } & \multicolumn{10}{|c|}{ CP fractions } \\
\hline & \multicolumn{2}{|c|}{ A1 } & \multicolumn{2}{|c|}{ A2 } & \multicolumn{2}{|c|}{ B1 } & \multicolumn{2}{|c|}{ B2 } & \multicolumn{2}{|c|}{$\mathbf{C}$} \\
\hline & Mean & SEM & Mean & SEM & Mean & SEM & Mean & SEM & Mean & SEM \\
\hline Sudan grass & $67.4^{\mathrm{a}}$ & 5.2 & 504.0 & 7.0 & 186.6 & 12.7 & $142.3^{\mathrm{a}}$ & 4.6 & $99.7^{\mathrm{a}}$ & 2.2 \\
\hline Alfalfa & $83.8^{\mathrm{b}}$ & 4.3 & $539.3^{\mathrm{a}}$ & 7.5 & 222.0 & 10.7 & $115.0^{\mathrm{b}}$ & 6.4 & $39.9^{b}$ & 2.3 \\
\hline Red clover & 72.6 & 6.4 & $488.1^{\mathrm{b}}$ & 13.6 & 219.3 & 12.2 & $166.8^{\mathrm{a}}$ & 1.8 & $53.2^{\mathrm{c}}$ & 1.6 \\
\hline $\mathrm{AF} \times \mathrm{SG}$ & 73.6 & 4.1 & 509.2 & 10.3 & 195.4 & 11.6 & $142.1^{\mathrm{a}}$ & 3.1 & $79.7^{\mathrm{d}}$ & 2.2 \\
\hline $\mathrm{RC} \times \mathrm{SG}$ & 68.9 & 6.1 & $489.8^{\mathrm{b}}$ & 7.3 & 197.3 & 17.4 & $162.9^{\mathrm{a}}$ & 3.8 & $81.1^{\mathrm{d}}$ & 2.1 \\
\hline $\mathrm{P}$ & 0.046 & & 0.013 & & 0.643 & & 0.035 & & 0.007 & \\
\hline
\end{tabular}

AF $\times$ SG: Alfalfa-sudan grass mixture; RC $\times$ SG: Red clover-sudan grass mixture; SEM: Standard error of the mean; ${ }^{\text {a,b,c,d: }: \text { Values }}$ within a same column with different numerical superscripts differ significantly $(\mathrm{P}<0.05)$.

Crude protein fractions for the analyzed forages according to the Cornell Net Carbohydrate and Protein System are shown in Table 2 and Table 3.

Concentration of $\mathrm{NH}_{3}-\mathrm{N}$ in analyzed forage species was a quite similar, with a pronounced increase for silage, whereas sudan grass silage showed the lowest and alfalfa the highest value $(\mathrm{P}<0.05)$. The lowest concentration of protein fraction $\mathrm{A} 2$ was found in fresh and wilted red clover $(\mathrm{P}<0.001)$ and in hay $(\mathrm{P}<0.05)$ as well as in ensiled red clover and red clover-sudan grass mixture, especially compared to alfalfa silage $(\mathrm{P}<0.05)$. Ensiled sudan grass and alfalfa-sudan grass mixture had lesser values for soluble protein in comparison to alfalfa silage by 6.55 and $5.58 \%$, respectively. The crude protein fraction B1 was 
higher in legumes $(\mathrm{P}<0.001)$ than in sudan grass forage (fresh, wilted and hay). The notably less content of B1 fraction was determined in silages. Sudan grass and red clover showed greater values of fraction B2 than alfalfa forages $(\mathrm{P}<0.001)$. The higher content of moderately degradable protein fraction $(\mathrm{P}<0.05)$ was also determined in ensiled legume-sudan grass mixtures relative to alfalfa silage. Protein fraction $\mathrm{C}$ which is unavailable to the animals was significantly different between crops, with the largest values for sudan grass $(\mathrm{P}<0.001)$, and also was higher in red clover than alfalfa forages $(\mathrm{P}<0.001)$. Sudan grass showed the greatest content of $\mathrm{C}$ fraction which is a result of the highest ADF level.

Table 4 provides mean RDP values for fresh and wilted herbage and for hay. Protein degradability was greatly influenced by forage crops $(\mathrm{P}<0.001$ and $\mathrm{P}<0.05$, according to different procedures) with the highest determined degradability in alfalfa and the lowest in sudan grass. Protein degradability of sudan grass forages was lower by 7.2 to $7.9 \%$ or 10.4 to $15.7 \%$ (CNCPS or $S$. griseus procedure) and up to $0.8 \%$ or 5.3 to $9.7 \%$ in comparison with alfalfa and red clover, respectively. Sudan grass showed a lesser protein degradability than red clover forages. There was a lesser RDP content in red clover relative to alfalfa forages (6.5 to 7.5 or 4.3 to $6.6 \%$ ). Increased RDP was estimated according to CNCPS procedure in wilted sudan grass and alfalfa $(\mathrm{P}<0.01$ and $\mathrm{P}<0.05)$ as in sudan grass wilted herbage and hay $(\mathrm{P}<0.01)$ using the $S$. griseus procedure. Ensiled plant material was characterized with the substantially higher RDP values (Table 5).

The lowest RDP values $(\mathrm{P}<0.05)$ were in ensiled sudan grass and red clover-sudan grass mixture, while the estimated ruminal protein degradability was the highest in alfalfa silage $(\mathrm{P}<0.05)$, and the determined RDP values for red clover and alfalfa-sudan grass mixture were intermediate.

Table 6 shows the relationship between rumen degradable protein obtained using a Streptomyces griseus protease incubation and according the Cornell protein fractionation procedure. Estimated RDP values for the protease assay compared to crude protein fractionation were lower by 6.9 to $14.2 \%$ for different forage types, and also by 6.0 to $14.0 \%$ for different forage species and mixtures.

Table 4. Protein degradability of fresh and wilted herbage and hay (\% of CP).

\begin{tabular}{|c|c|c|c|c|c|c|c|}
\hline \multirow{2}{*}{ Forage } & \multicolumn{2}{|c|}{ Sudan grass } & \multicolumn{2}{|c|}{ Alfalfa } & \multicolumn{2}{|c|}{ Red clover } & \multirow[t]{2}{*}{$\mathbf{P}$} \\
\hline & Mean & SEM & Mean & SEM & Mean & SEM & \\
\hline \multicolumn{8}{|c|}{ CNCPS procedure } \\
\hline Fresh & $65.11^{\mathrm{ax}}$ & 0.27 & $70.18^{a y}$ & 0.14 & $65.65^{x}$ & 0.23 & $<0.001$ \\
\hline Wilted & $66.62^{\mathrm{bx}}$ & 0.37 & $72.04^{\mathrm{by}}$ & 0.18 & $66.62^{x}$ & 0.11 & $<0.001$ \\
\hline Hay & $65.30^{\mathrm{ax}}$ & 0.04 & $70.90^{\text {a y }}$ & 0.28 & $65.57^{x}$ & 0.25 & $<0.001$ \\
\hline $\mathrm{P}$ & 0.005 & & 0.024 & & 0.052 & & \\
\hline \multicolumn{8}{|c|}{ S. griseus procedure } \\
\hline Fresh & $52.37^{a x}$ & 0.45 & $62.10^{y}$ & 0.42 & $57.98^{z}$ & 0.55 & 0.009 \\
\hline Wilted & $57.50^{\mathrm{bx}}$ & 0.77 & $64.14^{y}$ & 0.80 & $61.41^{\mathrm{y}}$ & 0.89 & 0.017 \\
\hline Hay & $56.62^{\mathrm{bx}}$ & 0.59 & $63.45^{y}$ & 0.98 & $59.78^{x}$ & 1.25 & 0.033 \\
\hline $\mathrm{P}$ & 0.006 & & 0.716 & & 0.060 & & \\
\hline
\end{tabular}

SEM: Standard error of the mean; ${ }^{\text {a,b }}$ : Values within a same column with different numerical superscripts differ significantly $(\mathrm{P}<0.05) ;{ }^{\mathrm{x}, \mathrm{y}, \mathrm{z}}$ : Values within a same row with different letter superscripts differ significantly $(\mathrm{P}<0.05)$.

Table 5. Protein degradability of silages (\% of CP).

\begin{tabular}{lcccc}
\hline \multirow{2}{*}{ Ensiled herbage } & \multicolumn{2}{c}{ CNCPS procedure } & \multicolumn{2}{c}{ S. griseus procedure } \\
\cline { 2 - 5 } & Mean & SEM & Mean & SEM \\
\hline Sudan grass & $71.06^{\mathrm{a}}$ & 0.21 & $64.19^{\mathrm{a}}$ & 0.55 \\
Alfalfa & $77.50^{\mathrm{b}}$ & 0.14 & $72.12^{\mathrm{b}}$ & 0.48 \\
Red clover & $72.41^{\mathrm{c}}$ & 0.20 & $69.16^{\mathrm{b}, \mathrm{c}}$ & 0.24 \\
$\mathrm{AF} \times \mathrm{SG}$ & $73.23^{\mathrm{c}}$ & 0.18 & $67.75^{\mathrm{a}, \mathrm{c}}$ & 0.54 \\
$\mathrm{RC} \times \mathrm{SG}$ & $71.33^{\mathrm{a}}$ & 0.10 & $67.08^{\mathrm{a}, \mathrm{c}}$ & 0.56 \\
$\mathrm{P}$ & 0.026 & & 0.043 & \\
\hline
\end{tabular}

$\mathrm{AF} \times \mathrm{SG}$ : Alfalfa-sudan grass mixture; $\mathrm{RC} \times \mathrm{SG}$ : Red clover-sudan grass mixture; SEM: Standard error of the mean; ${ }^{\mathrm{a}, \mathrm{b}, \mathrm{c}}:$ Values within a same column with different numerical superscripts differ significantly $(\mathrm{P}<0.05)$. 
Table 6. Linear regression ( $\mathrm{Y}=a+b \times \mathrm{X})$ of forage RDP (\% of $\mathrm{CP})$ estimated by enzymatic degradation $(\mathrm{X})$ and by $\mathrm{CP}$ fractionation $(\mathrm{Y})$.

\begin{tabular}{lcccc}
\hline Forage & $\boldsymbol{a}$ & $\boldsymbol{b}$ & $\mathbf{R}^{\mathbf{2}}$ & SE \\
\hline Fresh & 39.161 & 0.48 & 0.73 & 1.31 \\
Wilted & 31.094 & 0.61 & 0.53 & 1.95 \\
Hay & 30.573 & 0.61 & 0.59 & 1.83 \\
Silage & 23.410 & 0.73 & 0.72 & 1.31 \\
\hline
\end{tabular}

$a, b$ : Values in linear regression equation; $\mathrm{R}^{2}$ : Coefficient of determination; SE: Standard error.

\section{Discussion and Conclusion}

Applied forage treatments did not significantly affect the chemical composition. A slight increase of fiber fractions in wilted herbage and hay was probably due to the result of losses associated with respiration (20) and for ensiled material due to the decrease in water soluble carbohydrate (1).

The CNCPS crude protein fractions were markedly influenced by the crops and forage types. Reduced soluble fraction in red clover may be related to the activity of polyphenol oxidase and subsequent formation of quinones which form complexes with proteins, decreasing their availability for proteases of plants and rumen microorganisms (10). Alfalfa had much lower B2 content due to its low level of NDF as stated by Edmunds et al. (6) for white clover. Values for slowly degradable protein bound in NDF are usually greater in grasses than in forage legumes at comparative growth stages (24). The nonsignificant increase of $\mathrm{NH}_{3}-\mathrm{N}$ and fraction $\mathrm{A} 2$, and somewhat reduced values for other protein fractions (primarily B1 fraction) in wilted herbage and hay was likely due to the result of proteolysis $(11,13)$. Soluble true protein was the main fraction in silage, which was combined with a particular decrease in B1 fraction, probably due to the extensive degradation by plant proteases (22). Ensiling had a tendency to reduce content of fraction $\mathrm{C}$.

Protein degradability values significantly differed among forage crops. The largest RDP values for alfalfa can be ascribed to high proportion of soluble true protein (A2) relative to red clover, higher B1 fraction than sudan grass, and its low cell wall associated $\mathrm{CP}$ fraction $(\mathrm{B} 2+\mathrm{C})$. Coblentz et al. (4) also reported the higher RDP estimates for alfalfa hay than that for grass hay. Lower protein degradability of the sudangrass than red clover forage found in the present study was likely due to the significant differences in content of moderately degradable and cell wall associated protein. Increased RDP values in wilted forage were in accordance with findings of Krawutschke et al. (17), which explained the decrease in RUP content in wilted legume herbage by negative correlations with the level of NPN and moderately degradable protein. The substantially higher RDP values in silages are due to the $\mathrm{CP}$ fraction distribution, where the soluble true protein is the main fraction in silage, which is combined with a multiple increase in ammonia N. However, one of the important finding is the significant reduction of $\mathrm{CP}$ degradability in ensiled legume-sudan grass mixtures, especially relative to alfalfa silage. The reduction of protein degradability by ensiling alfalfa-sudan grass mixture was 5.5 or $6.1 \%$ compared to alfalfa silage as well as 1.5 or $3.0 \%$ for ensiled red clover-sudan grass mixture relative to red clover silage. Lower forage and ration RDP content can significantly contribute to reducing ruminal ammonia-N concentration and improve nitrogen use efficiency (5).

The observed estimates for ruminal protein degradation according to the $S$. griseus protease procedure and CNCPS fractionation were highly related with each other. The enzymatic degradation using commercial protease (48 h $\mathrm{S}$. griseus assay) yields respective RDP estimates that are close to the known in vivo values (4), and explains a large portion of the variation observed from the in situ technique (21). Grabber (12) also found lower estimates of RDP by enzyme in vitro assay relative to the values from CNCPS fractionation according to Sniffen et al. (24).

The results from this study indicate the potential importance of using the sudan grass forages in order to increase the content of rumen undegradable protein (RUP) in the rations of ruminants. The sudan grass is characterized by a significantly lower crude protein degradability especially relative to the alfalfa forages, and also by a lower RDP content in comparison to red clover. Ensiling of legumes in combination with sudan grass improved $\mathrm{CP}$ fractions distribution that significantly reduces the protein degradability in comparison with pure legume silages. Red clover also showed an advantage relative to alfalfa forage according to the content and ratio of individual $\mathrm{CP}$ fractions and degradability. Positive effect of ensiling legume-sudan grass mixtures on reducing the crude protein degradability compared to legume silages, may be used for improvement of $\mathrm{N}$ utilization in ruminant nutrition. Degradable protein determined by an enzymatic procedure using S. griseus, although with slightly lower values, is in good agreement with predictions using the latest CNCPS v6.5 fractionation scheme. 


\section{Acknowledgements}

This research was conducted as a part of the project for technological development TR-31086 and the integral and interdisciplinary research project III-46012 of the Ministry of Education, Science and Technological Development, Republic of Serbia.

\section{Financial support}

This study was supported by the Ministry of Education, Science and Technological Development, Republic of Serbia under the contract number: 451-0368/2020-14/200116.

\section{Ethical Statement}

This study does not present any ethical concerns.

\section{Conflict of Interest}

The authors declared that there is no conflict of interest.

\section{References}

1. Amer S, Hassanat F, Berthiaume R, et al (2012): Effects of water soluble carbohydrate content on ensiling characteristics, chemical composition and in vitro gas production of forage millet and forage sorghum silages. Anim Feed Sci Tech, 177, 23-29.

2. AOAC (2002): Official methods of analysis. 17th ed. 1st revision. Association of Analytical Communities, Gaithersburg, MD, USA.

3. Canevari WM, Putnam DH, Lanini WT, et al (2000): Overseeding and companion cropping in alfalfa. University of California, Agriculture and Natural Resources, Oakland, CA, USA.

4. Coblentz WK, Abdelgadir IEO, Cochran RC, et al (1999): Degradability of forage proteins by in situ and in vitro enzymatic methods. J Dairy Sci, 82, 343-354.

5. Dijkstra J, Reynolds, CK, Kebreab E, et al (2013): Challenges in ruminant nutrition: towards minimal nitrogen losses in cattle. 47-58. In: JW Oltjen, E Kebreab, H Lapierre (Ed), Energy and protein metabolism and nutrition in sustainable animal production. Wageningen Academic Publishers, EAAP publication No. 134, The Netherlands.

6. Edmunds B, Südekum KH, Spiekers H, et al (2012): Estimating ruminal crude protein degradation of forages using in situ and in vitro techniques. Anim Feed Sci Tech, 175, 95-105.

7. Elizalde JC, Merchen NR, Faulkner DB (1999): Fractionation of fiber and crude protein in fresh forages during the spring growth. J Anim Sci, 77, 476-484.

8. Fijałkowska M, Pysera B, Lipiński K, et al (2015): Changes of nitrogen compounds during ensiling of high protein herbages: a review. Ann Anim Sci, 15, 289-305.

9. Frank B, Persson M, Gustafsson G (2002): Feeding dairy cows for decreased ammonia emission. Livest Prod Sci, 76, 171-179.

10. Gierus M, Herrmann A, Kruse S, et al (2006): Variation in the non-protein nitrogen content (fraction A) of several forages during the growing period. Grassland Sci Eur, 11, 595-597.

11. Grabber JH (2009a): Protein fractions in forage legumes containing protein-binding polyphenols: Freeze-drying vs. conservation as hay or silage. Anim Feed Sci Tech., 151, 324-329.

12. Grabber JH (2009b): Forage management effects on protein and fiber fractions, protein degradability, and dry matter yield of red clover conserved as silage. Anim Feed Sci Tech, 154, 284-291.

13. Guo XS, Ding WR, Han JG, et al (2008): Characterization of protein fractions and amino acids in ensiled alfalfa treated with different chemical additives. Anim Feed Sci Tech, 142, 89-98.

14. Higgs RJ, Chase LE, Ross DA, et al (2015): Updating the Cornell Net Carbohydrate and Protein System feed library and analyzing model sensitivity to feed inputs. J Dairy Sci, 98, 6340-6360.

15. Hristov AN, Bannink A, Crompton LA, et al (2019): Invited review: Nitrogen in ruminant nutrition: A review of measurement techniques. J Dairy Sci, 102, 5811-5852.

16. Hyams Development (2017): CurveExpert Professional, Version 2.6.3. Available at www.curveexpert.net. (Accessed March 01, 2020).

17. Krawutschke M, Weiher N, Thaysen J, et al (2013): The effect of cultivar on the changes in protein quality during wilting and ensiling of red clover (Trifolium pratense L.). J Agr Sci Cambridge, 151, 506-518.

18. Licitra G, Hernandez T, Van Soest PJ (1996): Standardization of procedures for nitrogen fractionation of ruminant feeds. Anim Feed Sci Tech, 57, 347-358.

19. Makoni NF, Shelford JA, Nakai S, et al (1993): Characterization of protein fractions in fresh, wilted, and ensiled alfalfa. J Dairy Sci, 76, 1934-1944.

20. Mathis CP, Cochran RC, Vanzant ES, et al (2001): $A$ collaborative study comparing an in situ protocol with single time-point enzyme assays for estimating ruminal protein degradability of different forages. Anim Feed Sci Tech, 93, 31-42.

21. Owens VN, Albrecht KA, Muck RE (1999): Protein degradation and ensiling characteristics of red clover and alfalfa wilted under varying levels of shade. Can J Plant Sci, 79, 209-222.

22. Pedersen JF, Fritz JO (2000): Forages and Fodder. 797810. In: CW Smith, RA Frederiksen (Ed), Sorghum: origin, history, technology and production. John Wiley \& Sons Inc, Hoboken, NJ, USA.

23. Reynal SM, Broderick GA (2005): Effect of dietary level of rumen-degraded protein on production and nitrogen metabolism in lactating dairy cows. J Dairy Sci, 88, 40454064.

24. Sniffen CJ, O'Connor JD, Van Soest PJ, et al (1992): A net carbohydrate and protein system for evaluating cattle diets: II. Carbohydrate and protein availability. J Anim Sci, 70, 3562-3577.

25. StatSoft. Inc. (2003): Statistica (data analysis software system), version 6.0. Available at www.statsoft.com. (Accessed March 01, 2020).

26. Tremblay GF, Michaud R, Bélanger G (2003): Protein fractions and ruminal undegradable proteins in alfalfa. Can J Plant Sci, 83, 555-559. 